\title{
Effect of feeding Yeast obtained from Sakhalin Buckwheat on the growth of broiler chickens
}

\author{
V.B. Tsugkieva, B.G. Tsugkiev, L.B. Dzantieva, A.T. Kokoeva, L. Kh. \\ Tokhtieva, I.A. Shabanova, E.A. Tokhtieva
}

Federal State Budgetary Educational Institution of Higher Education «Gorsky State Agrarian University», 37 , Kirova street, Vladikavkaz, Republic of North Ossetia-Alania, Russian Federation, 362040

E-mail: texmen2@mail.ru

Journal of Livestock Science (ISSN online 2277-6214) 12: 71-75

Received on 2/9/20; Accepted on 22/12/2020, Published on 15/1/2021

doi. 10.33259/JLivestSci.2021.71-75

\begin{abstract}
The feeding yeast, produced on a substrate prepared from the green mass of Sakhalin buckwheat, which has been introduced to the Republic of North Ossetia-Alania, contribute to the better development of chickens, increasing their productivity and reducing the cost of production. Experimental studies have been held to determine the effectiveness of yeast protein usage on broiler chickens. The research took place at a poultry farm in the Russian Federation, the city of Vladikavkaz. The research on Cross broiler chickens Ross 308 had been taking part during 56 days. We have determined the effect of yeast protein on the growth and the development of broiler chickens. We have also revealed the superiority of live weight and livestock safety of broiler chickens which received yeast protein in comparison with their control analogues that did not receive feeding yeast protein. The increase of live weight in a bird that has received feeding yeast from Sakhalin buckwheat is explained by the higher value of the yeast cell protein. It is established that a green mass of perennial is a biologically valuable, environmentally friendly source of production of a nutrient medium for growing yeast, it is high-yielding and not demanding to the conditions of plants' cultivation. The authors have found that the muscle mass in the best experimental groups is - the 1-st and the 2-nd-was $936.7 \mathrm{~g}$ and $902.2 \mathrm{~g}$, compared to $785.4 \mathrm{~g}$ in the control group, which is by $19.3 \%$ and $14.9 \%$ more than in the control group. The ratio of muscle mass to bone mass in the control group was 2.55 , compared to 2.73 and 2.71 in the best groups (according to their live weight) the 1-st and the 2-nd experimental groups, which is 7.0 and $6.3 \%$ more than in the control group. It has been found that the replacement of $5 \%$ and $3 \%$ of vegetable protein by the yeast protein, produced on the hydrolyzate of the green mass of Sakhalin buckwheat is effective and economically feasible to be used in the diets of broiler chickens.
\end{abstract}

Keywords: Sakhalin buckwheat; feeding yeast; broiler chickens; feeding ration; protein; productivity; Republic of North Ossetia-Alania. 


\section{Introduction}

Poultry accounts for about $33 \%$ of global meat production and is a source of protein that plays an important role in human nutrition (FAO, 2010). Modern intensive poultry farming releases finished products such as broiler chickens to the market within six weeks of their age. This achievement has resulted from increased productivity through genetic selection, improved feeding practices, and health management, including the use of antibiotics as therapeutic agents for treating bacterial diseases and as feed additives to promote growth (Spring, 2000).

The fundamental problem of poultry farming, which can be eliminated by the production of protein of single-celled organisms, in particular-yeast, is the lack of feed protein in the production of mixed feeds for poultry. Protein availability of feed rations for poultry can be solved by expanding crops and increasing the yield of legumes and oilseeds. However, the most promising is the production of yeast protein.

The widespread use of antibiotic substances in animal husbandry has contributed to the development of antibiotic therapy. This is due to the fact that bacteria have become more resistant to antibiotics and there is a deposition of antibiotic residues in animal products. Health and well-being, as well as food safety, are very important to the global control of antibiotic resistance. The widespread use of antibiotics to improve the effectiveness or control diseases, including salmonellosis in poultry, has contributed to the development of antibiotic-resistant bacteria and the deposition of residues in animal food. In Nigerian poultry farming, antibiotics are commonly used in feeding water and parenterally to prevent and treat infectious diseases, as well as to stimulate growth. Moreover, unregulated use of antibiotics is common in Nigerian poultry farming (Kabir, 2004; Olatoye, 2011).

The growing global threat of resistance to antibiotics and their residues has led to the search for alternative measures to reduce dependence on antibiotics in livestock food products. The use of antibiotics as a growth promoter was completely banned in 1999 by the European Union (EU) (European Commission, 2001).

Probiotics are viable microbial feed additives that promote growth and health, they have beneficial effect on the intestinal ecology (Breves, 2000; Simon, 2003). They have been successfully used to improve poultry health and achieve higher productivity (Peric, 2010). The beneficial effect of probiotics on the body is due to the better adhesion of bacteria to the intestinal epithelium, compared to pathogenic bacteria it stops the introduction of these bacteria through the intestinal mucosa (Bonomi, 1978). They are increasingly used as an alternative to improve the balance of intestinal microflora, as well as to improve the well-being and safety of food (Santin, 2011). The feeding yeast produced with the usage of gluten-the waste of starch production, apple pomace-the waste of canning production, and feed grains is highly nutritious additives in animal diets [Tsugkieva et al., 2009]. We revealed the dependence of the quality of feeding yeast on the type of raw materials and the technology for producing alcohol [Tsugkieva et al., 2010; Tsugkieva et al., 2010].

The Sakhalin buckwheat (Polygonum sachalinense FR. Schmidt) was first introduced to the Botanical garden of Gorsky State Agrarian University from Stavropol Botanical garden in 1971. For the second time, Sakhalin buckwheat was introduced by B. G. Tsugkiev, who started work on introducing this non-traditional crop to feed production. The expeditions of employees of the Gorsky Agricultural Institute (now Gorsky GAU) went to the island of Sakhalin twice, in order to collect planting material in natural populations (in autumn of 1985 and 1986). They collected seeds and rhizomes $(500 \mathrm{~kg}$ ). In the fall of 1986, a 0.25 -hectare plantation was laid on the Institute's experimental field. The imported seeds were sown in winter in greenhouses for growing seedlings, which were planted in the open ground in May 1987. Over time, the plantation was expanded to 6 hectares. Sakhalin buckwheat is also grown on large plots in the collection plant nursery of the research Institute of Biotechnology and in the Botanical garden of Gorsky GAU (B. G. Tsugkiev et al., 2017). The green mass of Sakhalin buckwheat is a promising raw material for the production of yeast protein. Sakhalin buckwheat was introduced in North Ossetia by Professor B. G. Tsugkiev, who has delivered the planting material from the Sakhalin island in 1985 and established Sakhalin buckwheat plantation on the Eastern outskirts of Vladikavkaz [Tmenov et al., 2006; Tokhtieva et al., 2003; Tokhtieva et al., 2017a; Tokhtieva et al., 2017b].

Long-term observations have shown that Sakhalin buckwheat is one of the most promising non-traditional forage crops in terms of its technological and economic parameters.

The Sakhalin buckwheat introduced in the Republic of North Ossetia Alania [Tokhtieva et al., 2002; Tokhtieva et al., 2003] is a perennial herb that reaches more than three to four meters in length, and the thickness of its stems is up to $3 \mathrm{~cm}$. Longitudinal lines of crimson color, they are clearly visible on a young, naked, slightly furrowed stem. A filmy brownish leaf that wraps around the stem sits on each of the nodes. At the place where its edges close, there is a petiolate leaf leaves, in the sinus of which a kidney develops. The stems are hollow inside. The lower and underground parts of the stem have the ability to intensively form roots, especially near the nodes. The leaves are glabrous, broadly oval in shape with a heart-shaped base and a short point, sometimes turned to the side. The average leaf size by the end of vegetation reaches a length of $25 \mathrm{~cm}$ and a width of $15 \mathrm{~cm}$. There are leaves up to $35 \mathrm{~cm}$ long and $20 \mathrm{~cm}$ wide. The leaves have a well-marked venation. The lateral veins are located asymmetrically, slightly arched; they quickly lose thickness and loop, connecting with each other, before reaching the edge. The grid of small veins is highly developed. Bell-shaped leaves are membranous, light brown, without cilia, very early destroyed. Buds are born in the sinus early and easily, which indicates a good reproductive ability of the plant. As the leaves mature, they begin to roughen, and the stems undergo a process of lignification. In late autumn, the stems become woody and remain dry till winter. They usually break out in winter. The root system is of the rhizomatous type. Young rhizomes are white, elastic. The rhizome eventually turns brown, covered with rings of fibrous roots, and new rhizomes or stem 
shoots develop from the kidneys, in the ground they have a pinkish hue. Along their entire length, roots are formed. The stem comes out of the ground still being pink.

The Sakhalin buckwheat is a hardy plant. Even in harsh winters of 2005 and 2006 years, its rhizomes were well preserved in the ground and in spring they produced numerous offsprings. However, young tender and watery buckwheat shoots were sometimes damaged by strong spring return frosts.

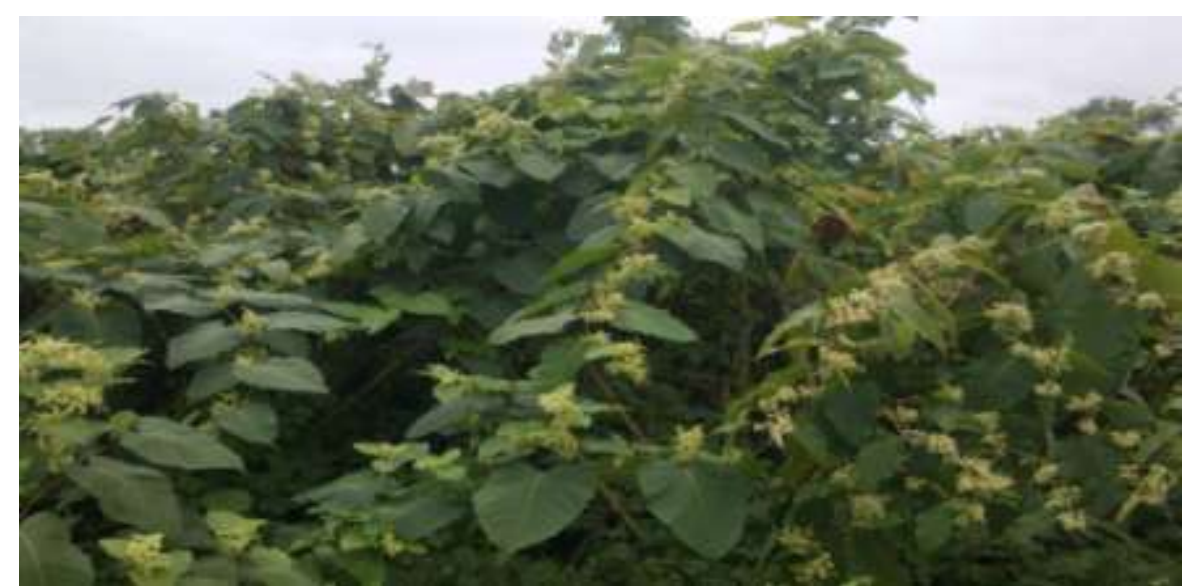

Fig 1. Sakhalin buckwheat (Polygonum sachalinense Fr. Schmidt) the picture is taken at the Botanical garden of the Gorsky State Agrarian University, Vladikavkaz, Russia.

Sakhalin buckwheat grows well in open areas, illuminated by the sun. Here it is particularly powerful. However, it can also grow in the shade. In the conditions of the University's Botanical garden, it can withstand the shade of coniferous trees. Strong shading does not prevent it from growing, but in this case it does not bloom.

It should be noted that the plants of the North Ossetian population of Sakhalin buckwheat exceed their counterparts, growing on Sakhalin Island in height, almost by 1 meter. However, the bushiness of this plant on Sakhalin is slightly superior to the North Ossetian population, although in terms of the yield of green mass, the superiority after two mowing remains on the side of the local, Ossetian population.

In the agro-climatic conditions of North Ossetia, Sakhalin buckwheat proved to be a high-yielding, fertilizerresponsive plant. The average yield of the green mass of this plant is $1370.3 \mathrm{C} /$ ha. The best dose of fertilizer for Sakhalin buckwheat is: manure $40 \mathrm{t} / \mathrm{ha}+N_{60} P_{90} K_{40}$ [Tsugkieva et al., 2010]. According to Tyutyunnikov, Tsugkiev and Smolenskiy (1998), the content of vitamin C in Sakhalin buckwheat increases as the phenophases of the plant's development change from $45.39 \mathrm{mg} / \%$ to $113.39 \mathrm{mg} / \%$ [Tyutyunnikov et al.,1996; Tyutyunnikov et al.,1998]. The yield of Sakhalin buckwheat in the Republic of North Ossetia- Alania ranges from 1350 to $1433 \mathrm{C} /$ ha [Tmenov et al., 2001]. It was found that the use of Sakhalin buckwheat in feed production, taking into account the high yield for two mowing and the nutrient-rich composition of dry matter, can play a positive role in strengthening the feed base of the Republic of North Ossetia-Alania, increasing the deficit of plant protein for balanced feeding of animals and poultry [Kiyashkina et al.,2002; Tmenov et al.,2005a; Tmenov et al., 2005b; Tsugkiev et al.,2017]. The information as above indicated that (i) Sakhalin buckwheat is an unconventional forage crop that significantly exceeds such forage crops as corn, amaranth and topinambur in terms of green mass yield; (ii) the natural and climatic conditions of the Republic of North Ossetia - Alania are quite consistent with the cultivation of Sakhalin buckwheat; (iii) a green mass of Sakhalin buckwheat is a rich composition of nutrients. Therefore the present study was undertaken to determine the effect of feeding Yeast obtained from Sakhalin Buckwheat on the growth of broiler chickens.

\section{Materials and methods}

The Yeast used in the present experiment was grown in a yeast-growing apparatus - fermenter - a biological reactor that serves for the accumulation of biomass. According to the method developed by B. G. Tsugkiev, the green mass of Sakhalin buckwheat was crushed, brought into stainless steel containers, acidified to a $\mathrm{pH}$ of 2.5 and autoclaved at 1.5 ATM for one hour for hydrolysis of polysaccharides. The hydromodule was 1:5.

After hydrolysis, the level of reducing sugars was determined in the hydrolysate, the $\mathrm{pH}$ was raised with $\mathrm{CaOH}$ solution to $4.0-4.5$, filtered, brought to a boil, urea was introduced at the rate of $4 \mathrm{~g}$ per 11 of hydrolysate, cooled to $35^{\circ} \mathrm{C}$, poured into fermenters, filling them with $2 / 3$ of the working volume, and yeast starter culture was introduced at the rate of $10 \%$ of the volume of the cultivated hydrolysate. Yeast cultivation was carried out at a temperature of $30-35^{\circ} \mathrm{C}$ with constant stirring and air supply at the rate of $60 \mathrm{~m}^{3}$ per $1 \mathrm{~m}^{3}$ of the nutrient medium per hour.

We selected 6 groups of broiler chickens of daily age, consisting of 100 heads in each group, to conduct experimental studies on feeding broiler chickens. The scheme of experience is shown in table 1 . The difference in feeding experimental groups of broiler chickens consisted in partial replacement of plant protein in the diets of experimental groups with protein from feed yeast, produced from the green mass of Sakhalin buckwheat (table 1). 
Tsugkieva et al 2021/ J. Livestock Sci. 12: 71-75

Table 1 - The Scheme of Experiment on Broilers $(n=100)$

\begin{tabular}{|c|c|}
\hline Group & Feeding Characteristics \\
\hline Control & Basic Diet $(\mathrm{BD})$ \\
\hline $1-$ experimental & $95 \%$ protein BD $+5 \%$ yeast protein \\
\hline $2-$ experimental & $97 \%$ protein BD $+3 \%$ yeast protein \\
\hline $3-$ experimental & $99 \%$ protein BD $+1 \%$ yeast protein \\
\hline
\end{tabular}

\section{Results and Discussion}

The dynamics of live weight of chickens was determined by weekly weighing. Live weight indicators of experimental broiler chickens are shown in table 2.

Table 2- The Dynamics of Broiler Chickens' Live Weight, $g(n=100)$

\begin{tabular}{|c|c|c|c|c|}
\hline \multirow{2}{*}{$\begin{array}{c}\text { The Age of } \\
\text { chickens }\end{array}$} & \multicolumn{4}{|c|}{ Group } \\
\cline { 2 - 5 } & Control & experiment 1 & experiment 2 & Experiment 3 \\
\cline { 2 - 5 } 0 day & 35 & 35 & 35 & 35 \\
\hline 56 days & $2060 \pm 72$ & $2250 \pm 75$ & $2200 \pm 49$ & $2100 \pm 41$ \\
\hline
\end{tabular}

By their live weight, broilers of three experimental groups that received yeast protein were superior at the age of 56 days in comparison with their counterparts from the control group: group $1-$ by $9.2 \%(\mathrm{P}>0.95)$, group $2-$ by $6.8 \%(\mathrm{P}>0.95)$ and group $3-$ by $1.9 \%(\mathrm{P}<0.95)$, respectively. Therefore, the most effective way to grow broiler chickens is to replace $5 \%$ of vegetable protein in the feeding rations with yeast protein produced on hydrolyzate from the green mass of Sakhalin buckwheat.

Feeding yeast had an impact not only on the growth energy of broilers, but also on the safety of livestock. Thus, the safety of broilers in the 1-experimental group was $98 \%$, which is $7 \%$ higher than in the control group. High safety of broilers (95 and 96\%) was also noted in the second and third experimental groups.

One of the main indicators that characterize the feed quality of broilers is their meat quality. The analysis of the results shows that the best among the experimental groups was a bird that received $5 \%$ of yeast protein as part of the feeding diet. The carcass yield in the 1 st experimental group was higher by $1.9 \%$. At the same time, the mass of the gutted carcass in this group is higher than in the control group by $18.3 \%$. The difference in the mass of edible parts of broiler chicken carcasses between the experimental and control groups is significant. Thus, in the 1-st experimental group, it exceeded the control group by $18.5 \%$ and in the $2-$ nd experimental group- by $14.2 \%$. Muscle mass in the best experimental groups - the 1st and the 2nd-was $936.7 \mathrm{~g}$ and $902.2 \mathrm{~g}$, compared to $785.4 \mathrm{~g}$ in the control group, which is $19.3 \%$ and $14.9 \%$, respectively, more than in the control group. The ratio of muscle mass to bone mass in the control group was 2.55 , compared to 2.73 and 2.71 in the best (live weight) the 1-st - and the 2-nd experimental groups, which is $7.0 \%$ and $6.3 \%$ more than in the control group.

It has been found that the replacement of $5 \%$ and $3 \%$ of vegetable protein in the feeding rations of broiler chickens by yeast protein, produced on the hydrolyzate of the green mass of Sakhalin buckwheat, is effective and economically feasible.

\section{References}

1) Bonomi A. and Vassia G. 1978. Observations and Remarks on the Use of Saccharomyces Cerevisiae and Kluyveromyces Fragilis, in the Form of Living Yeast, on the Production and Quantitative Characteristics of Broilers. Archivio Veterinario Italiano 29: 3-15.

2) Breves G., Walter C., Burmeister M., Shroder B. 2000. In Vitro Studies on the Effects of Saccharomyces Boulardii and Bacillus Cereus var. Toyoi on Nutrient Transport in Pig Jejunum. Journal of Animal Physiology and Animal Nutrition 84: 9-20

3) European Commision 2001. The 2-nd Opinion on Anti-microbial Resistance Available from: http://ec.europa.eu/food/fs/sc/ssc/ out203_en.pdf [cited 2009 Feb 11].

4) FAO 2010. Hand Book of Poultry Meat. http://www.responsibleagroinvestment.org

5) Kabir J., Umoh V.J., Audu-okoh E., Umoh J.U. and Kwaga J.K.P. 2004. Veterinary Drug Used in Poultry Farms and Determination of Antimicrobial Drug Residues in Commercial Eggs and Slaughtered Chicken in Kaduna State, Nigeria. Food Control 15: 99-105.

6) Kiyashkina L.A., Tsugkiev B.G., Tokhtieva L.Kh. 2002. The Chemical Composition of Some Forage Plants in the Conditions of North Ossetia Alania . The Proceedings of Gorsky State Agrarian University. 39: 78-81.

7) Olatoye I.O. 2011. Antibiotics' Use and Resistance Patterns of Salmonella Species in Poultry from Ibadan, Nigeria. Tropical Veterinarian 29: 28-35.

8) Peric L., Milosevic N., Zikic D., Bjedov S., Cvetkovic D., Markov S., Mohnl M., Steiner T. 2010. Effect of Probiotic and Phytobiotic Products on Performance, Gut Morphology and Cecal Microflora of Broiler Chicks. Archiv fur Tierzucht (Archive Animal Breeding) 53: 350-359. 
9) Santin E., Maiorka A., Macari M., Grecco M., Sanchez J.C., Okada T.M. and Myasaka A.M., 2001.The Performance and Intestinal Mucosa Development of Broiler Chickens Fed Diets Containing Saccharomyces Cerevisiae Cell Wall. Journal of Applied Poultry Research, 10: 236-244.

10) Simon O., Vahjen W., Scharek L. 2003. Microorganisms as Feed Additive-Probiotics; The Proceedings of the 9th International Symposium on Digestive Physiology in Pigs; Banff, Alberta, Canada. 14-17 May 2003.

11) Spring P., Wenk C., Dawson K.A., Newman K.E. 2000. The Effects of Dietary Mannanoligosaccharides on Cecal Parameters and the Concentrations of Enteric Bacteria in the Ceca of Salmonella-challenged Broiler Chicks. Poultry Science 79:205-211.

12) Tmenov I.D., Tsugkiev B.G., Mugnieva L.A., Tsotsiev R.L. 2001. Sakhalin Buckwheat as an Unconventional High-yielding Perspective Forage Crop. Vladikavkaz, 79 p.

13) Tmenov I.D., Tsugkieva V.B., Tokhtieva L. Kh. 2005a. The Use of Animal Feed, Enriched with Extract of Green Mass of Sakhalin Buckwheat in Feeding Broiler Chickens and Laying Hens. The Collection of Scientific-practical Conference "Actual Problems of Ecology and Nature Management". - Stavropol, 2005 a. 2: 445-448.

14) Tmenov I.D., Tsugkieva V.B., Tokhtieva L. Kh. 2005b. The Impact of Liquid Feed Yeast from Sakhalin Buckwheat on Fattening Qualities of Broiler Chickens. International Scientific and Practical Conference "The Achievements of Zootechnical Science and Practice is the Basis for the Development of Animal Production". Volgograd, 271-273.

15) Tmenov I.D., Tsugkieva V.B., Tokhtieva L.Kh. 2006. Liquid Fodder Yeast as a Source of Protein Poultry. 4: 33.

16) Tokhtieva L.Kh., Kiyashkina L.A., Tsugkiev B.G. 2002. The Phenology of Japanese Knotweed Development in the Conditions of North Ossetia-Alanya-Alanya. The Proceedings of Gorsky State Agrarian University. 39: 81- 83.

17) Tokhtieva L.Kh., Tsugkieva V.B. 2003. Knotweed as a New Promising Forage Plant in the Conditions of North Ossetia-Alania. The Proceedings of the North Caucasian Regional Conference "Student Science- Ecology of Russia" Vladikavkaz, Pp. 93-97.

18) Tokhtieva L.Kh., Tsugkieva V.B. 2003a. The Peculiarities of Japanese Knotweed Reproduction in the Conditions of North Ossetia-Alania. Modern Problems of Formation of the Strategy of Sustainable Development of Regional Agriculture. - Vladikavkaz, Pp. 217.

19) Tokhtieva L.Kh., Tsugkiev B.G., Tsugkieva V.B. 2017a. Knotweed as a Rich Source of Mineral Elements. Materials of all-Russian Scientific-practical Conference with the International Participation Dedicated to the Memory of Professor Saprygin George Petrovich. The Prospects of Food Production the New Generation Pp. 208-210.

20) Tokhtieva L.Kh., Tsugkiev B.G. 2017b. The Efficiency of Sakhalin Buckwheat in North Ossetia / The Materials of the International Scientific and Practical Conference, Dedicated to the Anniversary of the Scientistbreeder, Honored Inventor of the Russian Federation, Honored Scientist of RSO-Alania, Doctor of Agricultural Sciences, Professor Sarah Abramovna Bekuzarova "Current and New Directions in Breeding and Seed Production of Agricultural Crops" Pp. 133-134.

21) Tsugkiev B.G., Khoziev A.M., Tsugkieva V.B., Ramonova Z.G. 2017. The Efficiency of Bioconversion of Plant and Animal Raw Materials with Different Types of Yeast. Monograph. Vladikavkaz, 215 p.

22) Tsugkieva E.B., Tokhtieva L.Kh., Tsugkiev B.G. 2006. The Influence of Liming of Gray Forest Soil on the Productivity of Sakhalin Buckwheat. The Bulletin of Scientific Works of Young scientists of Gorsky GAU. 4: 5.

23) Tsugkieva V.B., Tsugkieva E.B., Dzantieva L.B. 2009. The Production of Feeding Yeast from Gluten, Fruit Pomace and Forage Grain. The Topical Issues of Animal Science and Practice as a Basis for Improving the Productive Qualities and Health of Farm Animals: The Proceedings of the International Scientific and Practical Conference, 26-27 November 2009, Stavropol, Pp. 237-239.

24) Tsugkieva V.B., Dzantieva L.B., Tsugkieva I.B. 2010. The Quality of Feeding Yeast Depending on the Production Technology and the Type of Raw Material New Directions in Solving the Problems of Agriculture Based on Modern Resource-saving Innovative Technologies: The Materials of the International Scientific and Practical Conference Dedicated to the 65th Anniversary of Victory in the Great Patriotic War, 26-28 January 2010-Volgograd, Pp. 164-166.

25) Tsugkieva V.B., Dzantieva L.B., Tsugkieva I.B. 2010. The Yeast Based on Flour of Sorghum Increases Milk Yield. Animal Husbandry In Russia. 5: 55-57.

26) Tyutyunnikov A.I., Tsugkiev B.G., Smolinsky E.A. 1996. The Chemical Composition of Non-traditional Feed and Medicinal Plants. Moscow: Rosselkhozacademy. 135 p.

27) Tyutyunnikov A.I. 1998. More Complete Use of the Productive Potential of Plants as an Urgent Task. Plant Resources and Biotechnology in Agriculture: TEZ. docl. International Scientific and Practical Conf. Vladikavkaz, Pp. 174-183. 